\title{
Non-genomic biomarkers of risk in ovarian cancer
}

\author{
Simone P. Pinheiro ${ }^{\mathrm{a}}$ and Daniel W. Cramer ${ }^{\mathrm{b}, *}$ \\ ${ }^{a}$ Department of Epidemiology, Harvard School of Public Health, Boston, MA, USA \\ ${ }^{\mathrm{b}}$ Obstetrics and Gynecology Epidemiology Center, Brigham and Women's Hospital (BWH), Harvard Medical \\ School, Boston, MA, USA
}

\section{Introduction}

Cancer biomarkers are biologic substances able to measure molecular, cellular, tissue, or host factors associated with cancer susceptibility, pathogenesis, response to treatment, or survival. Most familiar are serum biomarkers associated with cancer progression like the classic tumor markers, CEA, CA 125, CA 15.3, or PSA. Their use has been extended to early detection as well as surrogate endpoints in prevention or treatment trials. Many "classic" biomarkers are secreted by cancer cells or are direct consequences of the tumor diathesis; and their levels closely correlate with tumor burden. However, other biomarkers may not depend upon a cancer being present. Rather, they may reflect risk for or susceptibility to cancer.

There are several reasons why susceptibility or risk biomarkers might represent an attractive strategy to reduce the morbidity and mortality of ovarian cancer. Risk biomarkers might point to options for chemoprevention; e.g. raising levels of a nutrient that appears to be deficient. Even if the risk biomarker suggests no obvious prevention strategy, women identified to be at very high levels of risk for ovarian cancer could be offered prophylactic surgery. Primary prevention of ovarian cancer through removal ovaries and tubes in high-

\footnotetext{
* Corresponding author: Daniel W. Cramer, M.D., Sc.D., Obstetrics, Gynecology and Reproductive Biology, Brigham and Women's Hospital, 221 Longwood Avenue, Boston MA, 02115, USA. Tel.: +1 617732 4895; Fax: +1 617732 4899; E-mail: dcramer@ partners.org.
}

risk women is already a reality through BRCA1 and BRCA2 genetic testing, but such testing is costly and may pertain to only $10 \%$ of women who may develop ovarian cancer. Alternatively, risk biomarkers might identify women who might be suitable for more intensive screening. In this paper, we review non-genomic risk biomarkers for ovarian cancer under the following categories: micro and macronutrients, growth factors and hormones, inflammatory markers, and mucins and antibodies against them. We begin with a brief discussion of methodologic aspects affecting the discovery and application of susceptibility biomarkers for ovarian cancer.

\section{Methodologic considerations}

Several factors hamper the ease of investigating risk biomarkers for ovarian cancer. Case-control methodology that has been most commonly used to study ovarian cancer has the obvious limitation that the cancer cases are generally studied after diagnosis or therapy. Thus, the cancer itself may affect immune or inflammatory markers, while surgical removal of the ovaries will clearly alter levels of any hormones related to the ovarian/pituitary axis. Circulating nutrient levels are likely to be altered by the disease itself, as tumor growth may affect nutritional status, as well as by chemotherapy. Thus, study of the level of a potential biomarker many months (or years) prior to diagnosis is fundamentally important. However, the relatively low incidence of ovarian cancer (ovarian cancer is approximately 9 
times less frequent than breast cancer) makes the use of prospective study designs particularly costly and inefficient. Despite this, several cohorts are large and now mature enough so that a sufficient number of ovarian cancer cases have accumulated, making the study of risk biomarkers possible.

Another important issue to be considered is whether it is realistic to expect that a single measurement of a biomarker can capture the long-term biologic milieu in which a cancer may develop. Especially for a hormonal marker, variation by menopausal status, oral contraceptive or menopausal hormone use, phase of the menstrual cycle, or even time of day may make data from a single hormone measurement difficult to interpret. Williams and colleagues [1] showed that, aside from estrone sulfate and sex hormone binding globulin (SHBG), for which a one-time measurement captured most of the true variation in these hormone levels, a single measurement of any particular gonadotropin or sex steroid hormone is not representative of their longterm levels. Further difficulties arise from the histological diversity of ovarian cancer, where each type might be associated with distinct risk factors or susceptibility marker profiles. Finally, the etiology of ovarian cancer is not yet completely understood; thus, we don't have a clear roadmap of the biologic processes that should be targeted by potential risk biomarkers. Despite all these difficulties, several risk biomarkers have been investigated in hope they could point to a strategy to decrease the morbidity and mortality of ovarian cancer (summarized in Table 1).

\section{Micro- and macronutrients}

\subsection{Anti-oxidants}

Anti-oxidants are substances capable of reacting with or neutralizing free radicals (reactive oxygen and nitrogen species) that might otherwise cause genetic damage and promote carcinogenesis [2]. A variety of anti-oxidant micronutrients have been postulated to exert a protective effect on ovarian carcinogenesis, including carotenoids, alpha-tocopherol or vitamin E, vitamin $\mathrm{C}$, and selenium. Most of the studies have focused on estimating anti-oxidant intake using dietary questionnaires. Case-control studies comparing dietary intake or supplementation between women diagnosed with ovarian cancer (prior to disease) and cancer-free women have suggested the following antioxidants may reduce risk for ovarian cancer: vitamin E [3-6], vi- tamin C [4], vitamin A [3,7,8], carotenoids [9], betacarotene [3,5,6,8,10-12], and lycopene [13]. However, prospective epidemiologic studies based on dietary intake failed to provide evidence to support a role of increased intake of carotenoids [14-17], vitamin A [16], vitamin $C[15,16]$, or vitamin $E[14,15]$ in ovarian cancer risk. A few prospective studies have evaluated serum levels of micronutrients as markers of risk. Helzlsouer et al. [18] examined the association between the levels of several micronutrients and subsequent risk of ovarian cancer and found levels of carotenoids not to be associated with ovarian cancer risk [18]. For vitamin E or alpha-tocopherol, these authors found higher levels in women who developed ovarian cancer, suggesting that greater alpha-tocopherol levels increased subsequent risk, while no statistically significant difference was observed in alpha-tocopherol levels between women who became cases and their matched controls in a small study of ovarian cancer by Knekt et al. [19].

Selenium is another anti-oxidant that may be protective against cancers as suggested in several animal models [20] and ecological data showing inverse correlations between average selenium intake or selenium blood levels and cancer mortality $[21,22]$. The study of selenium intake through dietary sources is not an option because selenium levels in foods vary substantially according to the selenium content in the soil. Thus several epidemiologic studies have examined levels of selenium in serum or in finger or toenails to assess selenium intake in relation to cancer occurrence, including two studies of ovarian cancer. While in one study toenail selenium levels were not found to be associated with risk of developing ovarian cancer [23], Helzlsouer et al reported greater than $70 \%$ reduction in risk for those in the highest tertile of serum selenium levels after excluding women who were diagnosed within ovarian cancer 4 years after blood collection [18]. The discrepancy in findings is unlikely to be explained by differences in the medium in which selenium was measured in these two studies as toenail selenium seem to be highly correlated with serum selenium measurements $(r=0.89)$ [24]. Serum selenium was also not associated with risk of gynecologic malignancies in a study by Knekt et al. [25], but the number of ovarian cancer cases was not stated in this study.

\subsection{Vitamin $D$}

Vitamin D and its metabolites have been implicated in reducing the risk of several cancers, including ovarian. Some of the most commonly postulat- 
Table 1

Summary of studies examining non-genetic susceptibility biomarkers in ovarian carcinogenesis prospectively

\begin{tabular}{|c|c|c|c|c|c|}
\hline Marker & Study Design & Participants & Main Results & Assays & Reference \\
\hline \multicolumn{6}{|c|}{ Micro and macro nutrients } \\
\hline $\begin{array}{l}\text { Serum alpha- } \\
\text { tocopherol }\end{array}$ & $\begin{array}{l}\text { Case-control nested } \\
\text { within cohort (Finland) }\end{array}$ & $\begin{array}{l}16 \text { ovarian cancer cases } \\
\text { matched to } 29 \text { controls on } \\
\text { municipality and age }\end{array}$ & $\begin{array}{l}\text { No association with ovari- } \\
\text { an cancer risk }\end{array}$ & $\begin{array}{l}\text { Intra and inter-batch } \\
\mathrm{CV} \text { s }<10 \%\end{array}$ & $\begin{array}{l}\text { Knekt P. } \\
1988[19]\end{array}$ \\
\hline $\begin{array}{l}\text { Serum } \alpha \text { and } \gamma \text { - } \\
\text { tocopherol, } \alpha \text { and } \\
\beta \text {-carotene, retinol, } \\
\text { cryptoxanthin, } \\
\text { lutein, lycopene, } \\
\text { selenium, } \\
\text { cholesterol }\end{array}$ & $\begin{array}{l}\text { Case-control nested } \\
\text { within cohort (US) }\end{array}$ & $\begin{array}{l}35 \text { ovarian cancer cases } \\
\text { matched to } 67 \text { controls on } \\
\text { race, age, menopause, fast- } \\
\text { ing, and timing of blood } \\
\text { collection }\end{array}$ & $\begin{array}{l}\text { Elevated } \alpha \text {-tocopherol and } \\
\text { cholesterol associated with } \\
\text { increased risk of ovarian } \\
\text { cancer (p-trend } 0.04 \text { and } \\
0.02 \text { respectively). } \\
\text { Selenium associated with } \\
\text { decrease in risk (p trend } \\
0.02 \text { ). } \\
\text { Ovarian cancer risk not } \\
\text { associated with } \gamma \text { - } \\
\text { tocopherol, } \alpha \text { and } \beta \text { - } \\
\text { carotene, retinol, cryptox- } \\
\text { anthin, lutein, lycopene. }\end{array}$ & $\begin{array}{l}\text { CVs: }<10 \% \text { for all } \\
\text { micro nutrients } \\
\text { studied except for } \alpha \text { - } \\
\text { carotene }(16.7 \%) \text { and } \\
\text { cryptoxanthin } \\
(10.8 \%) .\end{array}$ & $\begin{array}{l}\text { Helzlsouer et al, } \\
1996 \text { [18] }\end{array}$ \\
\hline Serum cholesterol & Prospective cohort (US) & $\begin{array}{l}86,464 \text { participants, } \\
\text { ovarian cancer cases }\end{array}$ & $\begin{array}{l}\text { No association with ovari- } \\
\text { an cancer risk }\end{array}$ & CVs unavailable & $\begin{array}{l}\text { Hiatt and Fire- } \\
\text { man, } 1986[30]\end{array}$ \\
\hline Serum selenium & $\begin{array}{l}\text { Case-control nested } \\
\text { within cohort (Finland) }\end{array}$ & $\begin{array}{l}86 \text { gynecologic cancers } \\
\text { matched to } 172 \text { controls on } \\
\text { municipality and age. }\end{array}$ & $\begin{array}{l}\text { No association with risk of } \\
\text { gynecologic cancers }\end{array}$ & $\begin{array}{l}\text { Intra and inter-batch } \\
\mathrm{CVs}<10 \%\end{array}$ & $\begin{array}{l}\text { Knekt et al, } \\
1990[25]\end{array}$ \\
\hline Toe nail selenium & $\begin{array}{l}\text { Case-control study } \\
\text { nested within cohort } \\
\text { (US) }\end{array}$ & $\begin{array}{l}58 \text { ovarian cancer cases } \\
\text { matched to } 58 \text { controls on } \\
\text { age and date of sample } \\
\text { collection. }\end{array}$ & $\begin{array}{l}\text { No association with ovari- } \\
\text { an cancer risk }\end{array}$ & & $\begin{array}{l}\text { Garland et al, } \\
1995[23]\end{array}$ \\
\hline $\begin{array}{l}\text { Serum FSH, LH, an- } \\
\text { drostedione, DHEA } \\
\text { sulfate, estrone, } \\
\text { estradiol, } \\
\text { progesterone }\end{array}$ & $\begin{array}{l}\text { Case-control study nest- } \\
\text { ed within cohort (US) }\end{array}$ & $\begin{array}{l}\text { Hormonal bior } \\
31 \text { ovarian cancer cases } \\
\text { matched to } 62 \text { controls } \\
\text { on age, menopause status, } \\
\text { timing of blood collection }\end{array}$ & $\begin{array}{l}\text { Larkers } \\
\text { Lower FSH associated } \\
\text { with increased risk ( } p= \\
0.04 \text { ) } \\
\text { Elevated androstedione as- } \\
\text { sociated with increased } \\
\text { risk (p trend } 0.008 \text { ) } \\
\text { Indication of increased risk } \\
\text { with elevated DHEA sul- } \\
\text { fate (p trend } 0.11 \text { ) } \\
\text { LH, estrone, estradiol, pro- } \\
\text { gesterone not association } \\
\text { with ovarian cancer risk }\end{array}$ & $\begin{array}{l}\text { Intra and inter CVs } \\
\leqslant 10 \%\end{array}$ & $\begin{array}{l}\text { Helzlsouer et al, } \\
1995 \text { [37] }\end{array}$ \\
\hline $\begin{array}{l}\text { Urinary DHEA, an- } \\
\text { drostedione, and } \\
\text { aetiocholanolone }\end{array}$ & $\begin{array}{l}\text { Case-control study nest- } \\
\text { ed within cohort (Island } \\
\text { of Guernsey) }\end{array}$ & $\begin{array}{l}12 \text { ovarian cancer cases } \\
\text { matched to } 133 \text { controls on } \\
\text { age and menopause status. }\end{array}$ & $\begin{array}{l}\text { Lower androgens associ- } \\
\text { ated with increased risk } \\
\text { (DHEA } p=0.007 \text {, an- } \\
\text { drostedione } p=0.06 \text { ). } \\
\text { Aetiocholanone not asso- } \\
\text { ciated with ovarian cancer } \\
\text { risk }\end{array}$ & CVs unavailable & $\begin{array}{l}\text { Cuzick et al, } \\
1983 \text { [42] }\end{array}$ \\
\hline Serum LH & $\begin{array}{l}\text { Case-control study } \\
\text { nested within cohort } \\
\text { (US) }\end{array}$ & $\begin{array}{l}58 \text { ovarian cancer cases } \\
\text { matched to } 116 \text { controls } \\
\text { on age, menopause status, } \\
\text { timing of blood collection. }\end{array}$ & $\begin{array}{l}\text { No association with ovari- } \\
\text { an cancer risk }\end{array}$ & $\begin{array}{l}\text { Intra and inter CVs } \\
<10 \%\end{array}$ & $\begin{array}{l}\text { Akhmedkhanov } \\
\text { et al, 2001 [36] }\end{array}$ \\
\hline Serum FSH & $\begin{array}{l}\text { Pooled case-control } \\
\text { studies nested in } 3 \\
\text { cohorts (US, Sweden, } \\
\text { Italy) }\end{array}$ & $\begin{array}{l}88 \text { ovarian cancer cases } \\
\text { matched to } 168 \text { on age and } \\
\text { date of enrollment, cohort } \\
\text { (all postmenopausal) }\end{array}$ & $\begin{array}{l}\text { No association with ovari- } \\
\text { an cancer risk. }\end{array}$ & Intra CVs $<10 \%$ & $\begin{array}{l}\text { Arslan et al, } \\
2003[76]\end{array}$ \\
\hline $\begin{array}{l}\text { Serum testosterone, } \\
\text { androstedione, } \\
\text { DHEAS, SHBG, } \\
\text { estrone }\end{array}$ & $\begin{array}{l}\text { Pooled case-control } \\
\text { studies nested in } 3 \\
\text { cohorts (US, Sweden, } \\
\text { Italy) }\end{array}$ & $\begin{array}{l}132 \text { ovarian cancer cas- } \\
\text { es matched to } 168 \text { on } \\
\text { age, date of enrollment, } \\
\text { menopause status, cohort) }\end{array}$ & $\begin{array}{l}\text { Elevated androstedione in- } \\
\text { creased } \\
\text { ovarian cancer risk among } \\
\text { pre-menopausal women (p } \\
\text { trend } 0.12 \text { ). }\end{array}$ & & \\
\hline
\end{tabular}


Table 1, continued

\begin{tabular}{|c|c|c|c|c|c|}
\hline Marker & Study Design & Participants & Main Results & Assays & Reference \\
\hline & & & $\begin{array}{l}\text { Testosterone, DHEAS, } \\
\text { SHBG, estrone not asso- } \\
\text { ciated with ovarian cancer } \\
\text { risk. }\end{array}$ & $\begin{array}{l}\text { Intra CVs }<10 \%, \text { inter } \\
\mathrm{CVs} \leqslant 15.1 \%\end{array}$ & $\begin{array}{l}\text { Lukanova et al, } \\
2003 \text { [39] }\end{array}$ \\
\hline $\begin{array}{l}\text { Serum IGF-1 and } \\
\text { IGFBP-3 }\end{array}$ & $\begin{array}{l}\text { Pooled case-control } \\
\text { studies nested in } 3 \\
\text { cohorts (US, Sweden, } \\
\text { Italy) }\end{array}$ & $\begin{array}{l}132 \text { ovarian cancer cas- } \\
\text { es matched to } 168 \text { con- } \\
\text { trols on age, date of en- } \\
\text { rollment, menopause sta- } \\
\text { tus, and cohort. }\end{array}$ & $\begin{array}{l}\text { Increased IGF- } 1 \text { levels as- } \\
\text { sociated with increased } \\
\text { risk among women }<55 \text { (p } \\
\text { trend }<0.03 \text { ). } \\
\text { IGBPB-3 not associated } \\
\text { with ovarian cancer risk. }\end{array}$ & $\begin{array}{l}\text { Intra and inter batch } \\
\mathrm{CVs}<10 \% \text {. }\end{array}$ & $\begin{array}{l}\text { Lukanova et al, } \\
2002[51]\end{array}$ \\
\hline $\begin{array}{l}\text { Serum } \operatorname{IgF}-1 \text { and } \\
\text { IGFBP-3 }\end{array}$ & $\begin{array}{l}\text { Pooled case-control } \\
\text { studies nested in EPIC } \\
\text { cohort (Denmark, } \\
\text { France, Germany, } \\
\text { Greence, Italy, The } \\
\text { Netherlands, Spain, } \\
\text { The United Kingdom) }\end{array}$ & $\begin{array}{l}214 \text { cases matched to } 388 \\
\text { controls on study cen- } \\
\text { ter, menopause status, age, } \\
\text { time of blood collection, } \\
\text { fasting status, and phase } \\
\text { of menstrual cycle (in pre- } \\
\text { menopausal participants) }\end{array}$ & $\begin{array}{l}\text { Elevated IGF-1 associated } \\
\text { with increased risk among } \\
\text { women }<55 \text { years at di- } \\
\text { agnosis (p-trend } 0.08 \text { ) and } \\
\text { among women who were } \\
\text { pre-menopausal at blood } \\
\text { collection and }<55 \text { years at } \\
\text { diagnosis (p-trend } 0.02 \text { ) } \\
\text { Elevated } \\
\text { IGFBP-3 non-significantly } \\
\text { associated with increased } \\
\text { risk among women }<55 \\
\text { years at diagnosis }\end{array}$ & $\begin{array}{l}\text { Mean intrabatch } \\
\text { CVs }<4 \% \text {; mean } \\
\text { inter-batch CVs } \\
<13 \%\end{array}$ & $\begin{array}{l}\text { Peeters et al. } \\
2007 \text { [52] }\end{array}$ \\
\hline $\begin{array}{l}\text { Plasma IGF-1, } \\
\text { IGFBP-2, IGFBP-3 }\end{array}$ & $\begin{array}{l}\text { Pooled nested case- } \\
\text { control studies from } \\
3 \text { cohorts (US) }\end{array}$ & $\begin{array}{l}222 \text { ovarian cancer cases } \\
\text { matched to } 599 \text { controls on } \\
\text { menopause status, and age, } \\
\text { fasting status and PMH use } \\
\text { at blood collection. }\end{array}$ & $\begin{array}{l}\text { Suggestive of inverse as- } \\
\text { sociation between elevated } \\
\text { IGF-1 and cancer risk (p- } \\
\text { trend } 0.14 \text { ). } \\
\text { No significant associa- } \\
\text { tion between IGFBP-2 or } \\
\text { IGFBP-3 and cancer risk }\end{array}$ & $\begin{array}{l}\text { Intra-assay } \\
\leqslant 10 \%\end{array}$ & $\begin{array}{l}\text { Tworoger et al. } \\
2007 \text { [53] }\end{array}$ \\
\hline $\begin{array}{l}\text { Serum c-peptide, } \\
\text { IGFBP-1, IGFBP-2 }\end{array}$ & $\begin{array}{l}\text { Pooled case-control } \\
\text { studies nested in } 3 \\
\text { cohorts (US, Sweden, } \\
\text { Italy) }\end{array}$ & $\begin{array}{l}132 \text { ovarian cancer cas- } \\
\text { es matched to } 168 \text { con- } \\
\text { trols on age, date of en- } \\
\text { rollment, menopause sta- } \\
\text { tus, and cohort. } \\
\text { Inflammatory }\end{array}$ & $\begin{array}{l}\text { Elevated IGFBP-1 and } \\
\text { IGFBP-2 associated with } \\
\text { non-significant decrease in } \\
\text { risk (among women }<55 \\
\text { years) } \\
\text { C-peptide not associated } \\
\text { with ovarian cancer risk. } \\
\text { markers }\end{array}$ & $\begin{array}{l}\text { Intra and inter CVs } \\
\leqslant 11 \text { and } 16.2 \%\end{array}$ & $\begin{array}{l}\text { Lukanova et al, } \\
2003 \text { [47] }\end{array}$ \\
\hline Serum soluble Fas & $\begin{array}{l}\text { Pooled case-control } \\
\text { studies nested in } 3 \\
\text { cohorts (US, Sweden, } \\
\text { Italy) }\end{array}$ & $\begin{array}{l}138 \text { ovarian cancer cas- } \\
\text { es matched to } 263 \text { con- } \\
\text { trols on age, date of en- } \\
\text { rollment, menopause sta- } \\
\text { tus, and cohort. }\end{array}$ & $\begin{array}{l}\text { No association with ovari- } \\
\text { an cancer risk }\end{array}$ & $\begin{array}{l}\text { Intra and inter CVs } \\
<10 \%\end{array}$ & $\begin{array}{l}\text { Akhmedkhanov } \\
\text { et al, } 2003 \text { [59] }\end{array}$ \\
\hline Serum CA 125 & $\begin{array}{l}\text { Case-control nested } \\
\text { within cohort (JANUS } \\
\text { serum bank, Norway) }\end{array}$ & $\begin{array}{l}\text { Mucins } \\
105 \text { ovarian cancer cases } \\
\text { matched to } 323 \text { controls } \\
\text { on age, residence, time of } \\
\text { sample collection and sam- } \\
\text { ple storage conditions. }\end{array}$ & $\begin{array}{l}s \\
\text { Levels of CA } 125 \text { lower } \\
\text { among controls than cases } \\
\text { diagnosed up to } 12 \text { years } \\
(p<0.001)\end{array}$ & $\begin{array}{l}\text { Inter } \\
<15 \%\end{array}$ & $\begin{array}{l}\text { Zurawski et al, } \\
1988 \text { [31] }\end{array}$ \\
\hline Serum CA 125 & $\begin{array}{l}\text { Case-control study nest- } \\
\text { ed within cohort (US) }\end{array}$ & $\begin{array}{l}37 \text { ovarian cancer cases } \\
\text { matched to } 73 \text { controls on } \\
\text { age and time since last } \\
\text { menstrual period. }\end{array}$ & $\begin{array}{l}\text { Levels of CA } 125 \text { lower } \\
\text { among controls than cases } \\
\text { diagnosed up to } 12 \text { years } \\
\text { after blood collection }(p= \\
0.002) \text {. }\end{array}$ & $\begin{array}{l}\text { Intra batch CVs } \\
\text { ranged from } 6 \text { to } 16 \% \\
\text { depending on CA } 125 \\
\text { concentrations }\end{array}$ & $\begin{array}{l}\text { Helzlsouer et al, } \\
1993 \text { [65] }\end{array}$ \\
\hline Serum CA 125 & $\begin{array}{l}\text { Prospective cohort (In- } \\
\text { terventional screening } \\
\text { study) }\end{array}$ & $\begin{array}{l}22,000 \text { post-menopausal- } \\
\text { women, } 49 \text { ovarian or } \\
\text { epithelial cancer cases }\end{array}$ & $\begin{array}{l}\text { CA } 125 \text { levels }>30 \mathrm{U} / \mathrm{ml} \\
\text { associated with increased } \\
\text { risk of ovarian cancer (OR } \\
\text { and } 95 \% \text { CI within five } \\
\text { years after screen: } 14.3 \\
(8.5,24.3)\end{array}$ & $\begin{array}{l}\text { Intra and inter CVs } \\
<10 \%\end{array}$ & $\begin{array}{l}\text { Jacobs et al, } \\
1996[66]\end{array}$ \\
\hline
\end{tabular}


ed mechanisms explaining the potential protective effects of vitamin D include inhibition of angiogenesis and enhancement of cell adherence, which in turn inhibit cell proliferation and may protect against tumorigenesis. Several ecologic studies have reported that ovarian cancer mortality is higher in areas of lower sunlight or lower dietary vitamin D intake (reviewed in [26]). A group of investigators have recently examined the relation between serum vitamin $\mathrm{D}$ metabolites (25-hydroxyvitamin D and 1,25-dihydroxyvitamin D) and risk of developing ovarian cancer in a case-control study nested within the Nurses Health Study. Overall, circulating levels of vitamin D metabolites did not seem to be associated with subsequent risk of developing ovarian cancer, although a protective effect of 25-hydroxyvitamin D was suggested among obese and overweight women ( $p=0.04$ ) [27], which will need to be replicated in further prospective studies.

\subsection{Cholesterol}

There has been some epidemiologic evidence to suggest that dietary fats, including cholesterol, may increase risk of certain cancers including ovarian malignancies $[10,28]$. One biologic rationale for the potential influence of high cholesterol in ovarian carcinogenesis is that cholesterol is a steroid precursor that could lead to increased biosynthesis of estrogens, which may increase ovarian cancer risk. However, in a recent pooled analysis of 12 cohort studies of dietary fats, Genkinger et al. [29] found no evidence for a role of dietary fat or cholesterol in ovarian cancer risk. Thus, it is not surprising that the association between serum cholesterol levels and subsequent risk of ovarian cancer, explored to date in only two prospective studies, produced inconclusive findings. Helzlsouer et al. [18] reported a higher than 3-fold increase in ovarian cancer risk among women in the highest tertile of serum cholesterol levels compared to those in the lowest tertile. After excluding women diagnosed within 4 years of blood collection, the ORs for those in the highest tertile remained elevated, though no longer statistically significantly elevated (OR and 95\% CI: $2.9(0.7,11.3)$ ). In contrast to the findings reported by Helzlsouer et al,cholesterol levels were not found to be associated with ovarian cancer incidence in a large cohort where 190 women developed ovarian cancer over the course of up to 16 years of follow-up [30].

\section{Hormonal biomarkers}

\subsection{Gonadotropins}

It has been postulated that excessive stimulation of the ovaries by pituitary gonadotropins may increase risk of malignant transformation both directly and indirectly through stimulation of sex steroid production [31]. Animal models using ovarian irradiation or chemicals toxic to oocytes raised gonadotropin levels and produced ovarian tumors, albeit not entirely comparable to the epithelial tumors in women $[32,33]$. Results of epidemiologic studies compatible with an effect of gonadotropin include ovarian cancers observed after irradiation for cervical cancer [34] or protection associated with birth control pill use, which profoundly lower gonadotropins [35]. The association between prediagnostic levels of gonadotropins and ovarian cancer has been examined in only two studies. In one study, no association was found [36], and in the other an inverse association was observed. In this study, Helzlsouer et al. [37] reported lower gonadotropin levels (particularly follicle-stimulating hormone) in women subsequently diagnosed with ovarian cancer compared to controls, particularly among post-menopausal women. Although relatively small and based on a single measurement of gonadotropin levels, these studies fail to provide support for a role of circulating gonadotropins as markers of increased susceptibility to the development of ovarian cancer.

\subsection{Estrogens and progesterone}

Estrogen and progesterone production in the premenopausal woman occurs almost entirely in the ovaries where the synthesis of sex-steroid hormones is under the control of gonadotropins acting on the granulosa and theca cells of the developing follicle. Ovarian epithelial tumors, which have the appearance of estrogen-sensitive Mullierian tissues, may contain estrogen and progesterone receptors [38]. To date, only two studies have directly investigated the relation between circulating levels of estrogens and subsequent risk of ovarian cancer [37,39]. Both studies were null, providing no support for a major role of circulating estrogens on ovarian carcinogenesis. Lukanova et al. [39] also investigated the role of sex hormone-binding protein (SHBG), which is the major binding globulin of estradiol and determines the levels of biologically active estradiol. They found no influence of SHBG on ovarian cancer risk. In this study, repeated measure- 
ments of estrone and SHBG were obtained 11 to 60 months apart, and intra-class correlations of 0.89 for estrone (among post-menopausal women only) and of 0.89 for SHBG were reported.

Contrary to the presumed harmful effects of estrogen, progesterone excess has been postulated to be beneficial [40]. After the second month of pregnancy, the placental synthesis of progesterone is responsible for a close to 10-fold increase in the maternal circulating levels of progesterone, which led some to hypothesize that progesterone could account at least in part for the protective effects of pregnancy on ovarian cancer risk. However, the only study conducted to date to directly examine the association between levels of progesterone and subsequent risk of ovarian cancer found no convincing evidence for a role of progesterone on ovarian carcinogenesis [37].

\subsection{Androgens}

Androgens have also been proposed to increase ovarian cancer risk according to several lines of evidence reviewed by Risch [40]. Ovarian epithelial cells contain androgen receptors, and ovarian epithelial cell lines treated with androgens have shown increased proliferation rate and decreased rate of cell death [41]. Epidemiologic evidence supporting the androgen hypothesis include the protection conferred by oral contraceptive use, which reduce circulating levels of androgen and the increased risk observed with women diagnosed with Polycystic Ovarian Syndrome (PCOS), characterized by elevated circulating androgen levels.

More direct evidence for a role of androgens in the development of ovarian cancer was provided by 2 prospective studies [37,39], both of which showed an increased ovarian cancer risk (though non-significantly in one [39]) among those with elevated prediagnostic serum levels of androstenedione (particularly among pre-menopausal women). Interestingly, urinary androgens levels were shown to be lower in controls compared to cases in an earlier small prospective study conducted in the Island of Guernsey [42]. However, the small size of this study (12 cases) increases the probability that chance played a role in their findings. Alternatively, it is possible that higher urinary concentrations of androgens do not correspond to elevated circulating levels of androgens.

\subsection{Insulin}

Insulin has both mitogenic and anti-apoptotic properties and has been implicated in several cancers, including colon, breast, and pancreatic cancer [43]. Insulin may influence ovarian cancer risk on one hand by stimulating LH-induced androgen production, and on the other hand by downregulating the expression of sex hormone binding globulin (SHBG) and insulin-like growth (IGF) factor binding protein 1, thereby influencing levels of biologically active, free circulating sex steroids hormones and IGF-I [40,44]. Despite an appealing biologic rationale, epidemiologic data have not provided clear support for a role for insulin in ovarian carcinogenesis. Conditions intimately associated with increased insulin production such as obesity and type II diabetes mellitus have been shown to exert minimal or no effect on ovarian cancer risk, respectively $[45,46]$. The only prospective study examining the association between circulating c-peptide levels, a marker of pancreatic insulin secretion, also failed to provide support for a role of insulin in ovarian cancer [47].

\subsection{Insulin-Like Growth Factor and its binding protein}

The mitogenic and anti-apoptotic properties of IGF-I are well documented. Elevated concentrations of IGF-I are believed to play a role in the etiology of several types of cancers, including pre-menopausal breast, and prostate, lung, and colorectal cancers $[48,49]$. IGF-I and its binding proteins are thought to influence the regulation of ovarian follicular development and to have mitogenic and anti-apoptotic effects on ovarian epithelial cells [50]. Three prospective studies have examined the role of elevated IGF-I levels in ovarian carcinogenesis. In two studies, higher circulating IGF-I levels were associated with 2.4 to 4.7 fold increase in risk of ovarian cancer among women diagnosed at relatively young ages [52]. This increase in risk was accentuated among women who were pre-menopausal at blood collection (higher tertile associated with 5.6 fold increase in risk) [52]. Paradoxically, elevated IGF-1 levels were suggestive of a decrease in ovarian cancer risk in a recent pooled nested case-control study ( $\mathrm{p}$-trend non significant); their results did not appear to differ according to age at diagnosis or menopausal status [53]. Several IGF binding proteins are known to exist and function to reduce both availability of IGF-I and its biologic activity. Increasing levels of IGF binding proteins 1 and 2 were reported to exert a non-significant protective ef- 
fect on subsequent ovarian cancer risk among women diagnosed before the age of 55 in a study by Lukanova et al. [49]. Although no clear relation between IGF binding protein 3 was observed in most prospective studies, Peeters et al. [52] suggested a non-significant increase in risk with increasing concentrations among women diagnosed before the age of 55 years.

\section{Inflammatory biomarkers}

To address some of the shortcomings of earlier epidemiologic models for ovarian cancer based on incessant ovulation or gonadotropin excess, Ness and Cottreau [54] offered their theory that inflammation might explain the role of a number of risk factors for ovarian cancer including talc use, endometriosis, and ovulation. The process of inflammation involves the production of free radicals and recruitment of inflammatory mediators such as cytokines and prostaglandins, which can be mutagenic and contribute to the development of cancer including ovarian. Several inflammatory mediators have been found to be elevated in ovarian cancer tumors and some were associated with disease progression. Cytokines including TNF- $\alpha$, IL-6, IL-1 $\alpha$ and IL- $1 \gamma$ were found to be elevated in ovarian tumors and in women with ovarian tumors. Levels of TNF$\alpha$ were found to be indicative of ovarian tumor grade while levels of several inflammatory markers such as IL-6, IL-8, and VEGF were found to be indicative of early stage ovarian tumors [55-58].

Because presence of tumor is likely to induce inflammatory responses, it is important that studies examine the role of inflammatory biomarkers measured (preferably) several years before diagnosis. Akhmedkhanov et al. [59] examined the association between levels of soluble Fas and the risk of developing ovarian cancer in a case-control study nested within 3 cohort studies. Soluble Fas is a member of the tumor necrosis factor receptor family, is one of the major regulators of cellular apoptosis in many physiologic processes, and dysregulation of Fas-mediated apoptosis has been postulated to play a role in ovarian tumorigenesis [60]. Despite the strong biologic rational, Akhmedhanov et al. [59] found that serum soluble Fas did not differ between cases and controls failing to show that soluble Fas would be a useful susceptibility marker in ovarian carcinogenesis.

\section{Mucins and antibodies against them}

\subsection{Epithelial mucins}

The epithelial mucins are soluble or membranebound glycoproteins that are products of the human mucin family of genes. The first mucin to be described was MUC1, also known as CA 15.3. MUC 1 is an especially ubiquitous glycoprotein that occurs along the apical border of epithelial cells lining the genital, respiratory, and digestive tracts and breast ducts. With cancer, mucins become over-expressed and are released into the circulation and have thus become valuable tumor markers. MUC 1 has been proposed as a potential marker of for breast, pancreatic, endometrial, colon, and lung cancer. For ovarian cancer the best known mucin marker is MUC16, originally called CA 125. However, other mucins have also been studied as potential markers of ovarian carcinogenesis. Mucins MUC1, MUC2, MUC4, and MUC5AC were found to be expressed in epithelial ovarian cancer cells; MUC3 and MUC4 were associated with tumor stage and prolonged survival [61].

One of the most widely studied mucins, MUC16, or CA 125, has been approved as a marker for the monitoring of ovarian cancer, but has also been used as a potential marker for early detection. Several studies have found CA 125 to be elevated shortly prior to diagnosis of ovarian cancer [62-64]. More intriguing, however, are studies that suggest CA 125 may be elevated many years prior to cancer. In a nested case-control study, Zurawski et al. [31] showed that prediagnostic CA 125 levels as low as $10 \mathrm{U} / \mathrm{ml}$ were associated with a close to 4-fold increase in risk of developing ovarian cancer over 12 years of follow-up. In this study, median CA 125 levels were consistently higher among women who subsequently developed ovarian cancer 2,3 , or 5 years after blood collection, compared to controls. Helzlsouer et al. [65] also observed higher median CA 125 levels in cases compared to controls within 12 years of follow up, although this finding was only significant for the cases diagnosed within the first 3 years of blood collection. In this small nested case-control study, CA 125 levels as low as $10 \mathrm{U} / \mathrm{ml}$ were associated with a greater than 5-fold increase in risk of developing ovarian cancer over 12 years of follow-up. In a more recent interventional screening study of post-menopausal women, Jacobs and colleagues [66] reported that elevated blood levels of CA $125(\geqslant 30 \mathrm{U} / \mathrm{ml})$ were associated with a 14-fold increase risk of developing ovarian or fallopian tube cancers within the first 5 years of CA blood 


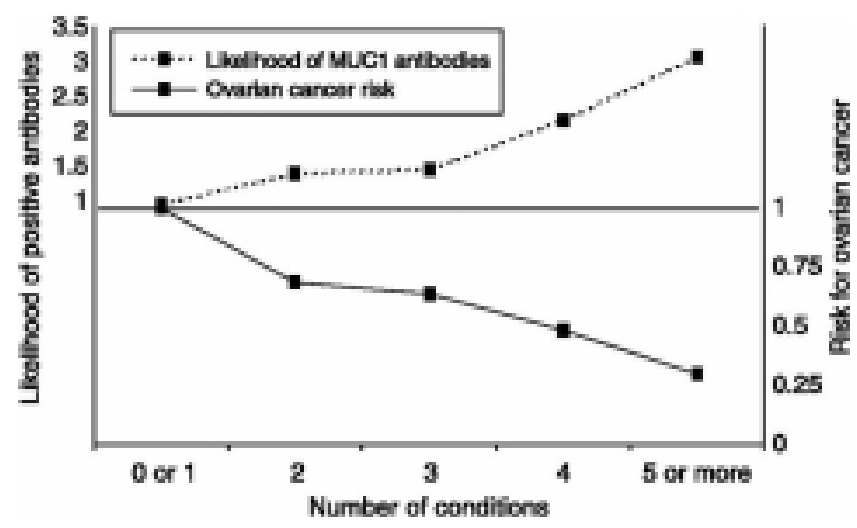

Fig. 1. Likelihood of testing positive for anti-MUC1 antibodies and risk of ovarian cancer as function of the number of protective events over a woman's lifetime (reprinted from Cramer et al. [71]).

measurements. Clearly there remains some uncertainty in these studies whether CA 125 is serving as an early detection or a risk biomarker, as some women who developed ovarian cancer shortly after blood collection were included in these analyses. However, the fact that CA 125 levels were noted to be higher in women who developed ovarian cancer 4 to 12 years after blood collection compared to those who remained cancer-free, suggests a role for CA 125 as a marker of susceptibility for ovarian cancer [65] in addition to its more recognized role as a recurrence biomarker. Further and larger prospective studies in which blood levels are measured a decade or more before the development of the cancer may be necessary to help us better define the role of CA 125 levels in ovarian cancer susceptibility.

\subsection{Anti-MUC1 antibodies}

An epidemiologic basis for proposing immunity as a basis for interpreting cancer risk probably dates back to 1980 with the "fetal antigen" theory for breast cancer [67]. This theory proposed that, during a pregnancy, women are exposed to fetal antigens that may be similar to antigens expressed by breast tumors and form an immunity to them that may account, at least in part, for the long-term protective effect of pregnancy on breast cancer risk. Later it was proposed that the cell surface glycoprotein and human mucin (MUC) family member, MUC1, might be the hypothetical immunity-inducing antigen since it is both secreted during pregnancy and over expressed in breast cancer [68]. It has been shown that sera from multiparous women - but not from nulliparous women or from men - are able to mediate killing of breast cancer cells. Supporting a key role for MUC1 in these reactions, core-peptide sequences from
MUC1 can induce proliferation of T cells and cytotoxic $\mathrm{T}$ cell responses in multiparous women [69]. The "fetal antigen" hypothesis was extended to ovarian cancer after it was shown that sera from multiparous women also reacted with multiple antigens from ovarian cancer cells more strongly than sera from nulliparous women or men [70], although MUC1 was not specifically examined in these experiments.

Because it is known that many cancers, including ovarian, over-express epithelial mucin, MUC1, and promote anti-MUC1 antibodies that correlate with more favorable prognosis, it was recently proposed that risk for ovarian cancer might be reduced by pre-existing MUC-1 specific immunity [71]. In this paper, antiMUC1 antibodies were measured in 705 control women, and events were identified that predicted antibodies. Ovarian cancer risk was then estimated by comparing profiles of events generating antibodies in controls with those in 668 ovarian cancer cases. Factors predicting antibodies included oral contraceptive use, breast mastitis, bone fracture or osteoporosis, pelvic surgeries, non-use of talc in genital hygiene, and to a lesser extent intrauterine device use and current smoking. There was a significant increase in the likelihood of having anti-MUC1 antibodies from $24.2 \%$ in women with 0 or 1 condition, to $51.4 \%$ in those with 5 or more conditions. By the same index of events, the risk for ovarian cancer was inversely associated with number of conditions predisposing to anti-MUC1 antibodies. Compared to having experienced 0 or 1 event, the adjusted risk for ovarian cancer decreased progressively with RRs (and 95\% CI) of $0.69(0.52,0,92), 0.64$ (0.47, 0.88), 0.49 (0.34, 0.72), and $0.31(0.16,0.61)$, respectively for women with $2,3,4$, and 5 or more events related to the presence of antibodies ( $p$ for trend 
$<0.0001$ ) (Fig. 1). The authors concluded that several traditional and new risk factors for ovarian cancer may be explained by their ability to induce MUC1 immunity through exposure of MUC1 to immune recognition in the context of inflammatory or hormonal processes in various MUC1-positive tissues.

Although intriguing, it should be appreciated that the role of anti-MUC1 antibodies as risk biomarkers was not directly assessed in this case-control study but rather only inferred by comparing the frequency of events predicting antibodies in cases and controls. Thus the value of anti-MUC1 antibodies as a risk biomarker still needs to be assessed in pre-diagnostic sera. In addition, other immune antibodies to ovarian cancer antigens might also be useful as risk biomarkers including, for example, antibodies against MUC16.

\section{Discussion}

During the last decade, there has been an increased interest in the use of biomarkers in cancer research to identify early disease and better understand the acquired and inherited susceptibility to the development of cancer. Our review has focused on non-genomic risk biomarkers including nutrients, hormones, and inflammatory or immune factors. Despite a large number of case-control studies based on dietary estimates of nutrient intake, prospective studies of serum nutrient levels have not generally shown a good correlation with ovarian cancer risk. Among the micronutrients studied, it is possible that elevated selenium levels may indicate lower ovarian cancer risk and elevated vitamin $\mathrm{E}$ and cholesterol levels may indicate some increase in risk. However, inconsistencies in the studies and uncertain biological mechanisms connecting nutrients with ovarian carcinogenesis suggest the need for further prospective studies before a definitive chemopreventive plan involving nutrients is suggested, even though this may have popular appeal.

Regarding hormonal biomarkers of risk for ovarian cancer, we found little evidence to support a major role for estrogens, progesterone, SHBG, and insulin, in ovarian carcinogenesis. On the other hand, there is some evidence suggesting that increased circulating levels of IGF-I and androgens may indicate an increased risk of ovarian tumors, especially among pre-menopausal women. Although it is not yet certain how the latter two hormones might operate to increase ovarian cancer risk, it has been observed that androgens may synergize with IGF-I to increase proliferation of cancer cell lines [72,73]. From a chemoprevention standpoint the observation regarding IGF-I and Androgens are important since oral contraceptives are able to significantly lower both androgens and IGF-I [74, 75]. This provides an additional rationale for use of oral contraceptives to lower ovarian cancer risk in addition to its ability to reduce the damage from "incessant ovulation."

It is now generally accepted that inflammatory/immune factors may play important role in carcinogenesis including that related to the ovary. Although larger prospective studies that exclude women diagnosed within a couple of years of blood collection will be needed before definitive conclusions can be drawn, antibodies against MUC1 may prove to be a promising marker indicative of ovarian cancer risk. A better understanding of the role of MUC1 antibodies in ovarian carcinogenesis will provide greater insight into the etiology of this malignancy and may point towards novel treatment and prevention strategies against ovarian cancer.

In conclusion, at the present time, there does not seem to be enough evidence to suggest any biomarker with a strong enough impact on ovarian cancer risk to justify recommendations of preventive interventions such as the removal of ovaries or fallopian tubes. Rather, this review points to a few markers that may have important implications in chemoprevention or in the targeting women for more intensive screening.

\section{Acknowledgements}

This work was supported by U01CA08638, CA 054419, and 1P50CA105009 from the National Cancer Institute.

\section{References}

[1] A.E. Williams, G. Maskarinec, A.A. Franke and F.Z. Stanczyk, The temporal reliability of serum estrogens, progesterone, gonadotropins, SHBG and urinary estrogen and progesterone metabolites in premenopausal women, BMC Womens Health 2(13) (2002)

[2] Y. Sun, Free radicals, antioxidant enzymes, and carcinogenesis, Free Radic Biol Med 8 (1990), 583-599.

[3] S.E. McCann, K.B. Moysich and C. Mettlin, Intakes of selected nutrients and food groups and risk of ovarian cancer, Nutr Cancer 39 (2001), 19-28.

[4] A.T. Fleischauer, S.H. Olson, L. Mignone, N. Simonsen, T.A. Caputo and S. Harlap, Dietary antioxidants, supplements, and risk of epithelial ovarian cancer, Nutr Cancer 40 (2001), 9298. 
[5] E. Bidoli, C. La Vecchia, R. Talamini, E. Negri, M. Parpinel, E. Conti, M. Montella, M.A. Carbone and S. Franceschi, Micronutrients and ovarian cancer: a case-control study in Italy, Ann Oncol 12 (2001), 1589-1593.

[6] S.Y. Pan, A.M. Ugnat, Y. Mao, S.W. Wen and K.C. Johnson, A case-control study of diet and the risk of ovarian cancer, Cancer Epidemiol Biomarkers Prev 13 (2004), 1521-1527.

[7] T. Byers, J. Marshall, S. Graham, C. Mettlin and M. Swanson, A case-control study of dietary and nondietary factors in ovarian cancer, J Natl Cancer Inst 71 (1983), 681-686.

[8] K.H. Tung, L.R. Wilkens, A.H. Wu, K. McDuffie, J.H. Hankin, A.M. Nomura, L.N. Kolonel and M.T. Goodman, Association of dietary vitamin A, carotenoids, and other antioxidants with the risk of ovarian cancer, Cancer Epidemiol Biomarkers Prev 14 (2005), 669-676.

[9] E.R. Bertone, S.E. Hankinson, P.A. Newcomb, B. Rosner, W.C. Willet, M.J. Stampfer and K.M. Egan, A populationbased case-control study of carotenoid and vitamin A intake and ovarian cancer (United States), Cancer Causes Control 12 (2001), 83-90.

[10] H.A. Risch, M. Jain, L.D. Marrett and G.R. Howe, Dietary fat intake and risk of epithelial ovarian cancer, J Natl Cancer Inst 86 (1994), 1409-1415.

[11] M.L. Slattery, K.L. Schuman, D.W. West, T.K. French and L.M. Robison, Nutrient intake and ovarian cancer, Am J Epidemiol 130 (1989), 497-502.

[12] A. Engle, J.E. Muscat and R.E. Harris, Nutritional risk factors and ovarian cancer, Nutr Cancer 15 (1991), 239-247.

[13] D.W. Cramer, H. Kuper, B.L. Harlow and L. Titus-Ernstoff, Carotenoids, antioxidants and ovarian cancer risk in pre- and postmenopausal women, Int J Cancer 94 (2001), 128-134.

[14] L.H. Kushi, P.J. Mink, A.R. Folsom, K.E. Anderson, W. Zheng, D. Lazovich and T.A. Sellers, Prospective study of diet and ovarian cancer, Am J Epidemiol 149 (1999), 21-31.

[15] K.M. Fairfield, S.E. Hankinson, B.A. Rosner, D.J. Hunter, G.A. Colditz and W.C. Willett, Risk of ovarian carcinoma and consumption of vitamins $\mathrm{A}, \mathrm{C}$, and $\mathrm{E}$ and specific carotenoids: a prospective analysis, Cancer 92 (2001), 2318-2326.

[16] S.A. Silvera, M. Jain, G.R. Howe, A.B. Miller and T.E. Rohan, Carotenoid, vitamin A, vitamin $\mathrm{C}$, and vitamin $\mathrm{E}$ intake and risk of ovarian cancer: a prospective cohort study, Cancer Epidemiol Biomarkers Prev 15 (2006), 395-397.

[17] A. Koushik, D.J. Hunter, D. Spiegelman, K.E. Anderson, J.E. Buring, J.L. Freudenheim, R.A. Goldbohm, S.E. Hankinson, S.C. Larsson, M. Leitzmann, J.R. Marshall, M.L. McCullough, A.B. Miller, C. Rodriguez, T.E. Rohan, J.A. Ross, A. Schatzkin, L.J. Schouten, W.C. Willett, A. Wolk, S.M. Zhang and S.A. Smith-Warner, Intake of the major carotenoids and the risk of epithelial ovarian cancer in a pooled analysis of 10 cohort studies, Int J Cancer 119 (2006), 2148-2154.

[18] K.J. Helzlsouer, A.J. Alberg, E.P. Norkus, J.S. Morris, S.C. Hoffman and G.W. Comstock, Prospective study of serum micronutrients and ovarian cancer, J Natl Cancer Inst 88 (1996), 32-37.

[19] P. Knekt, Serum vitamin E level and risk of female cancers, Int J Epidemiol 17 (1988), 281-286.

[20] C. Ip, D.J. Lisk and J.A. Scimeca, Potential of food modification in cancer prevention, Cancer Res 54 (1994), 1957s1959s.

[21] R.J. Shamberger, S.A. Tytko and C.E. Willis, Antioxidants and cancer. Part VI. Selenium and age-adjusted human cancer mortality, Arch Environ Health 31 (1976), 231-235.
[22] G.N. Schrauzer, D.A. White and C.J. Schneider, Cancer mortality correlation studies-III: statistical associations with dietary selenium intakes, Bioinorg Chem 7 (1977), 23-31.

[23] M. Garland, J.S. Morris, M.J. Stampfer, G.A. Colditz, C.L. Spate, C.K. Baskett, B. Rosner, F.E. Speizer, W.C. Willett and D.J. Hunter, Prospective study of toenail selenium levels and cancer among women, J Natl Cancer Inst 87 (1995), 497-505.

[24] M.P. Longnecker, P.R. Taylor, O.A. Levander, M. Howe, C. Veillon, P.A. McAdam, K.Y. Patterson, J.M. Holden, M.J. Stampfer, J.S. Morris et al., Selenium in diet, blood, and toenails in relation to human health in a seleniferous area, $A m J$ Clin Nutr 53 (1991), 1288-1294.

[25] P. Knekt, A. Aromaa, J. Maatela, G. Alfthan, R.K. Aaran, M. Hakama, T. Hakulinen, R. Peto and L. Teppo, Serum selenium and subsequent risk of cancer among Finnish men and women, J Natl Cancer Inst 82 (1990), 864-868.

[26] C.F. Garland, F.C. Garland, E.D. Gorham, M. Lipkin, H. Newmark, S.B. Mohr and M.F. Holick, The role of vitamin D in cancer prevention, Am J Public Health 96 (2006), 252-261.

[27] S. Tworoger, I. Lee, J. Buring, B. Rosner, B. Hollis and S. Hankinson, Plasma 25-hydroxyvitamin D and 1,25dihydroxyvitamin D and risk of incident ovarian cancer, Cancer Epidemiol Biomarkers Prev 6 (2007), 783-788.

[28] D.W. Cramer, W.R. Welch, G.B. Hutchison, W. Willett and R.E. Scully, Dietary animal fat in relation to ovarian cancer risk, Obstet Gynecol 63 (1984), 833-888.

[29] J.M. Genkinger, D.J. Hunter, D. Spiegelman, K.E. Anderson, W.L. Beeson, J.E. Buring, G.A. Colditz, G.E. Fraser, J.L. Freudenheim, R.A. Goldbohm, S.E. Hankinson, K.L. Koenig, S.C. Larsson, M. Leitzmann, M.L. McCullough, A.B. Miller, C. Rodriguez, T.E Rohan, J.A. Ross, A. Schatzkin, L.J. Schouten, E. Smit, W.C. Willett, A. Wolk, A. ZeleniuchJacquotte, S.M. Zhang and S.A. Smith-Warner, A pooled analysis of 12 cohort studies of dietary fat, cholesterol and egg intake and ovarian cancer, Cancer Causes Control 17 (2006), 273-285.

[30] R.A. Hiatt and B.H. Fireman, Serum cholesterol and the incidence of cancer in a large cohort, J Chronic Dis 39 (1986), 861-870.

[31] V.R. Zurawski, Jr., H. Orjaseter, A. Andersen and E. Jellum, Elevated serum CA 125 levels prior to diagnosis of ovarian neoplasia: relevance for early detection of ovarian cancer, Int J Cancer 42 (1988), 677-680.

[32] J.S. Howell, J. Marchant and J.W. Orr, The induction of ovarian tumours in mice with 9:10-dimethyl-1:2-benzanthracene, $\mathrm{Br}$ J Cancer 8 (1954), 635-646.

[33] J. Furth and J. Butterworth, Neoplastic diseases occurring among mice subjected to general irradiation with X-rays, $\mathrm{Am}$ J Cancer 28 (1936), 66-95.

[34] F. Pettersson, S. Fotiou, N. Einhorn and C. Silfversward, Cohort study of the long-term effect of irradiation for carcinoma of the uterine cervix. Second primary malignancies in the pelvic organs in women irradiated for cervical carcinoma at Radiumhemmet 1914-1965, Acta Radiol Oncol 24 (1985), $145-151$.

[35] A.S. Whittemore, R. Harris and J. Itnyre, Characteristics relating to ovarian cancer risk: collaborative analysis of 12 US case-control studies. IV. The pathogenesis of epithelial ovarian cancer. Collaborative Ovarian Cancer Group, Am J Epidemiol 136 (1992), 1212-1220.

[36] A. Akhmedkhanov, P. Toniolo, A. Zeleniuch-Jacquotte, K.S. Pettersson and I.T. Huhtaniemi, Luteinizing hormone, its beta-subunit variant, and epithelial ovarian cancer: the go- 
nadotropin hypothesis revisited, Am J Epidemiol 154 (2001), 43-49.

[37] K.J. Helzlsouer, A.J. Alberg, G.B. Gordon, C. Longcope, T.L. Bush, S.C. Hoffman and G.W. Comstock, Serum gonadotropins and steroid hormones and the development of ovarian cancer, Jama 274 (1995), 1926-1930.

[38] N.G. Ordonez, Value of estrogen and progesterone receptor immunostaining in distinguishing between peritoneal mesotheliomas and serous carcinomas, Hum Pathol 36 (2005), 1163-1167.

[39] A. Lukanova, E. Lundin, A. Akhmedkhanov, A. Micheli, S. Rinaldi, A. Zeleniuch-Jacquotte, P. Lenner, P. Muti, C. Biessy, V. Krogh, F. Berrino, G. Hallmans, E. Riboli, R. Kaaks and P. Toniolo, Circulating levels of sex steroid hormones and risk of ovarian cancer, Int J Cancer 104 (2003), 636-642.

[40] H.A. Risch, Hormonal etiology of epithelial ovarian cancer, with a hypothesis concerning the role of androgens and progesterone, J Natl Cancer Inst 90 (1998), 1774-1786.

[41] R.J. Edmondson, J.M. Monaghan and B.R. Davies, The human ovarian surface epithelium is an androgen responsive tissue, Br J Cancer 86 (2002), 879-885.

[42] J. Cuzick, J.C. Bulstrode, I. Stratton, B.S. Thomas, R.D. Bulbrook and J.L. Hayward, A prospective study of urinary androgen levels and ovarian cancer, Int J Cancer 32 (1983), 723-726.

[43] D.B. Boyd, Insulin and cancer, Integr Cancer Ther 2 (2003), 315-329.

[44] K.R. Kalli and C.A. Conover, The insulin-like growth factor/insulin system in epithelial ovarian cancer, Front Biosci 8 (2003), d714-d722.

[45] A.I. Adler, N.S. Weiss, M.L. Kamb and J.L. Lyon, Is diabetes mellitus a risk factor for ovarian cancer? A case-control study in Utah and Washington (United States), Cancer Causes Control 7 (1996), 475-478

[46] A. Engeland, S. Tretli and T. Bjorge, Height, body mass index, and ovarian cancer: a follow-up of 1.1 million Norwegian women, J Natl Cancer Inst 95 (2003), 1244-1248.

[47] A. Lukanova, E. Lundin, A. Micheli, A. Akhmedkhanov, S. Rinaldi, P. Muti, P. Lenner, C. Biessy, V. Krogh, E. Riboli, G. Hallmans, F. Berrino, A. Zeleniuch-Jacquotte, P. Toniolo and R. Kaaks, Risk of ovarian cancer in relation to prediagnostic levels of C-peptide, insulin-like growth factor binding proteins-1 and -2 (USA, Sweden, Italy), Cancer Causes Control 14 (2003), 285-292.

[48] R. Druckmann and U.D. Rohr, IGF-1 in gynaecology and obstetrics: update 2002, Maturitas 41(Suppl 1) (2002), S6583.

[49] H. Yu and T. Rohan, Role of the insulin-like growth factor family in cancer development and progression, J Natl Cancer Inst 92 (2000), 1472-1489.

[50] C.A. Conover, L.C. Hartmann, S. Bradley, P. Stalboerger, G.G. Klee, K.R. Kalli and R.B. Jenkins, Biological characterization of human epithelial ovarian carcinoma cells in primary culture: the insulin-like growth factor system, Exp Cell Res 238 (1998), 439-449.

[51] A. Lukanova, E. Lundin, P. Toniolo, A. Micheli, A. Akhmedkhanov, S. Rinaldi, P. Muti, P. Lenner, C. Biessy, V. Krogh, A. Zeleniuch-Jacquotte, F. Berrino, G. Hallmans, E. Riboli and R. Kaaks, Circulating levels of insulin-like growth factor-I and risk of ovarian cancer, Int J Cancer 101 (2002), 549-554.

[52] P.H.M. Peeters, A. Lukanova, N. Allen, F. Berrino, T. Key, L. Dossus, S. Rinaldi, C.H. Van Gils, H. Bas Bueno-deMesquita, H. Boeing et al., Serum IGF-I, its major binding protein (IGFBP-3) and epithelial ovarian cancer risk: the Euro- pean Prospective Investigation into Cancer Nutrition (EPIC), Endocrine-Related Cancer 14 (2007), 81-90.

[53] S.S. Tworoger, I.M. Lee, J.E. Buring, M.N. Pollak and S.E. Hankinson, Insulin-like growth factors and ovarian cancer risk: A nested case-control study in three cohorts, Cancer Epidemiol Biomarker Prev (2007), in press.

[54] R.B. Ness and C. Cottreau, Possible role of ovarian epithelial inflammation in ovarian cancer, J Natl Cancer Inst 91 (1999), 1459-1467.

[55] M.S. Naylor, G.W. Stamp, W.D. Foulkes, D. Eccles and F.R. Balkwill, Tumor necrosis factor and its receptors in human ovarian cancer. Potential role in disease progression, $\mathrm{J}$ Clin Invest 91 (1993), 2194-2206.

[56] F. Burke, M. Relf, R. Negus and F. Balkwill, A cytokine profile of normal and malignant ovary, Cytokine 8 (1996), 578-585.

[57] R. Punnonen, K. Teisala, T. Kuoppala, B. Bennett and J. Punnonen, Cytokine production profiles in the peritoneal fluids of patients with malignant or benign gynecologic tumors, Cancer 83 (1998), 788-796.

[58] E. Gorelik, D.P. Landsittel, A.M. Marrangoni, F. Modugno, L. Velikokhatnaya, M.T. Winans, W.L. Bigbee, R.B. Herberman and A.E. Lokshin, Multiplexed immunobead-based cytokine profiling for early detection of ovarian cancer, Cancer Epidemiol Biomarkers Prev 14 (2005), 981-987.

[59] A. Akhmedkhanov, E. Lundin, S. Guller, A. Lukanova, A. Micheli, Y. Ma, Y. Afanasyeva, A. Zeleniuch-Jacquotte, V. Krogh, P. Lenner, P. Muti, S. Rinaldi, R. Kaaks, F. Berrino, G. Hallmans and P. Toniolo, Circulating soluble Fas levels and risk of ovarian cancer, BMC Cancer 3 (2003), 33.

[60] R.L. Baldwin, H. Tran and B.Y. Karlan, Primary ovarian cancer cultures are resistant to Fas-mediated apoptosis, Gynecol Oncol 74 (1999), 265-271.

[61] R.L. Giuntoli, 2nd, G.C. Rodriguez, R.S. Whitaker, R. Dodge and J.A. Voynow, Mucin gene expression in ovarian cancers, Cancer Res 58 (1998), 5546-5550.

[62] N. Einhorn, K. Sjovall, R.C. Knapp, P. Hall, R.E. Scully, R.C. Bast, Jr. and V.R. Zurawski, Jr., Prospective evaluation of serum CA 125 levels for early detection of ovarian cancer, Obstet Gynecol 80 (1992), 14-18.

[63] I. Jacobs, A.P. Davies, J. Bridges, I. Stabile, T. Fay, A. Lower, J.G. Grudzinskas and D. Oram, Prevalence screening for ovarian cancer in postmenopausal women by CA 125 measurement and ultrasonography, Br Med J 306 (1993), 1030-1034.

[64] T.H. Bourne, S. Campbell, K. Reynolds, J. Hampson, L. Bhatt, T.J. Crayford, M.I. Whitehead and W.P. Collins, The potential role of serum CA 125 in an ultrasound-based screening program for familial ovarian cancer, Gynecol Oncol 52 (1994), 379-385.

[65] K.J. Helzlsouer, T.L. Bush, A.J. Alberg, K.M. Bass, H. Zacur and G.W. Comstock, Prospective study of serum CA 125 levels as markers of ovarian cancer, $J$ Am Med Assoc 269 (1993), 1123-1126.

[66] I.J. Jacobs, S. Skates, A.P. Davies, R.P. Woolas, A. Jeyerajah, P. Weidemann, K. Sibley and D.H. Oram, Risk of diagnosis of ovarian cancer after raised serum CA 125 concentration: a prospective cohort study, Br Med J 313 (1996), 1355-1358.

[67] D.T. Janerich, The influence of pregnancy on breast cancer risk: is it endocrinological or immunological? Med Hypotheses 6 (1980), 1149-1155.

[68] B.M.A.R. Agrawal, M.J. Krantz and B.M. Longenecker, Does pregnancy immunize against breast cancer? Cancer Res $\mathbf{5 5}$ (1995), 2257-2261.

[69] B. Agrawal, M.A. Reddish and B.M. Longenecker, In vitro induction of MUC-1 peptide-specific type 1 T lymphocyte and 
cytotoxic T lymphocyte responses from healthy multiparous donors, J Immunol 157 (1996), 2089-2095.

[70] L.B. Shields, C. Gercel-Taylor, C.M. Yashar, T.C. Wan, W.A Katsanis, J.A. Spinnato and D.D. Taylor, Induction of immune responses to ovarian tumor antigens by multiparity, $J$ Soc Gynecol Investig 4 (1997), 298-304.

[71] D.W. Cramer, L. Titus-Ernstoff, J.R. McKolanis, W.R. Welch, A.F. Vitonis, R.S. Berkowitz and O.J. Finn, Conditions associated with antibodies against the tumor-associated antigen MUC1 and their relationship to risk for ovarian cancer, Cancer Epidemiol Biomarkers Prev 14 (2005), 1125-1131.

[72] T.E. Hickey, D.L. Marrocco, F. Amato, L.J. Ritter, R.J. Norman, R.B. Gilchrist and D.T. Armstrong, Androgens augment the mitogenic effects of oocyte-secreted factors and growth differentiation factor 9 on porcine granulosa cells, Biol Reprod 73 (2005), 825-832.

[73] A. Yoshizawa and D.R. Clemmons, Testosterone and insulinlike growth factor (IGF) I interact in controlling IGF-binding protein production in androgen-responsive foreskin fibroblasts, J Clin Endocrinol Metab 85 (2000), 1627-1633.

[74] H. Jernstrom and H. Olsson, Suppression of plasma insulinlike growth factor-1 levels in healthy, nulliparous, young women using low dose oral contraceptives, Gynecol Obstet Invest 38 (1994), 261-265.

[75] H.C. Jernstrom, H. Olsson and A. Borg, Reduced testosterone, 17 beta-oestradiol and sexual hormone binding globulin, and increased insulin-like growth factor- 1 concentrations, in healthy nulligravid women aged 19-25 years who were first and/or second degree relatives to breast cancer patients, Eur $J$ Cancer Prev 6 (1997), 330-340.

[76] A.A. Arslan, A. Zeleniuch-Jacquotte, E. Lundin, A. Micheli, A. Lukanova, Y. Afanasyeva, P. Lenner, V. Krogh, P. Muti, S. Rinaldi, R. Kaaks, F. Berrino, G. Hallmans and P. Toniolo, Serum follicle-stimulating hormone and risk of epithelial ovarian cancer in postmenopausal women, Cancer Epidemiol Biomarkers Prev 12 (2003), 1531-1535. 


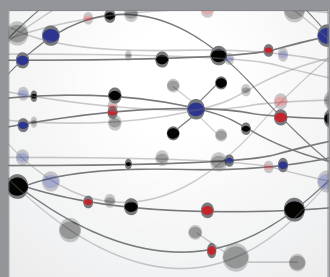

The Scientific World Journal
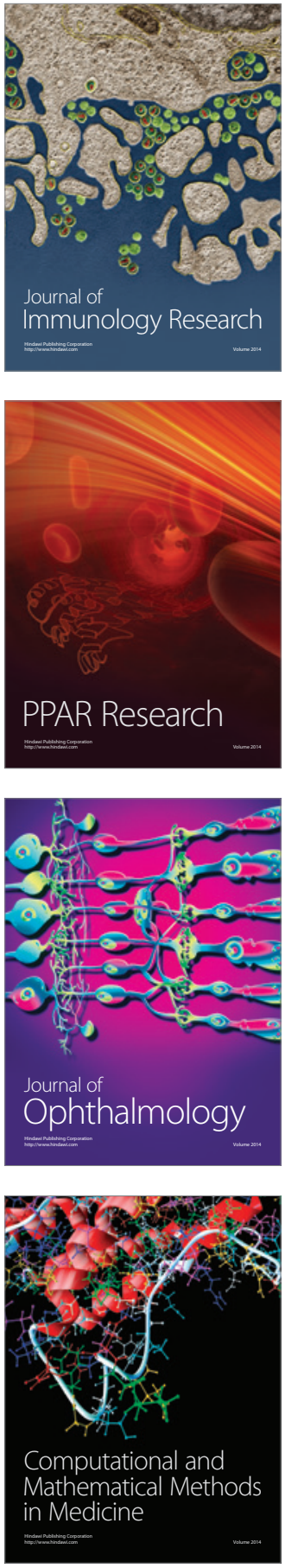

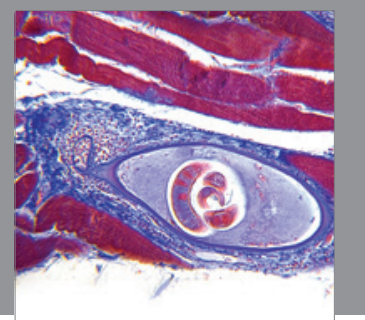

Gastroenterology

Research and Practice
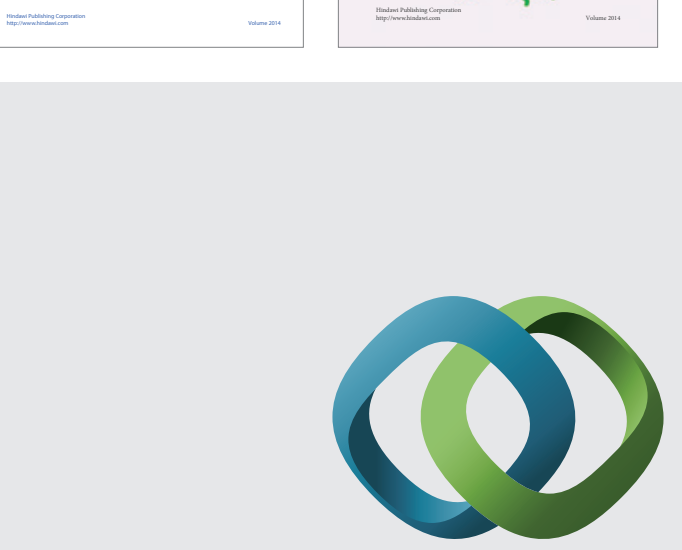

\section{Hindawi}

Submit your manuscripts at

http://www.hindawi.com
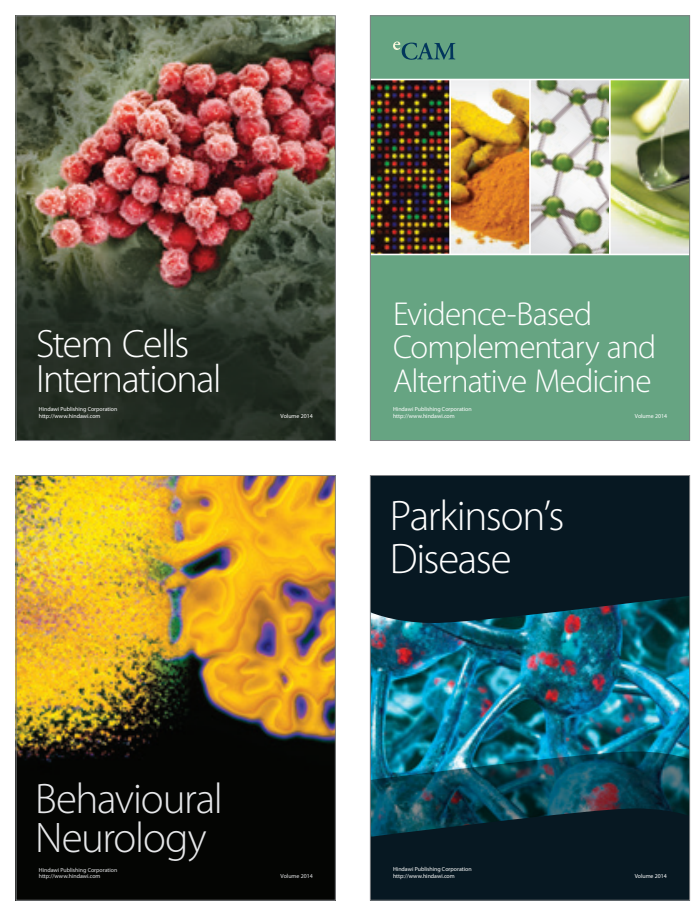

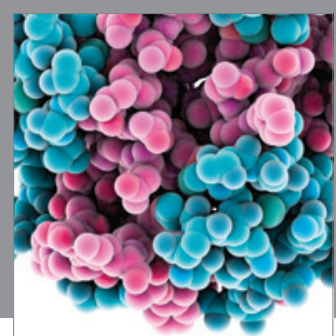

Journal of
Diabetes Research

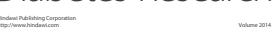

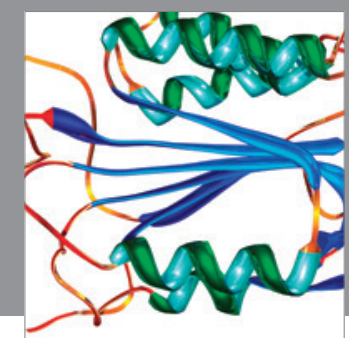

Disease Markers
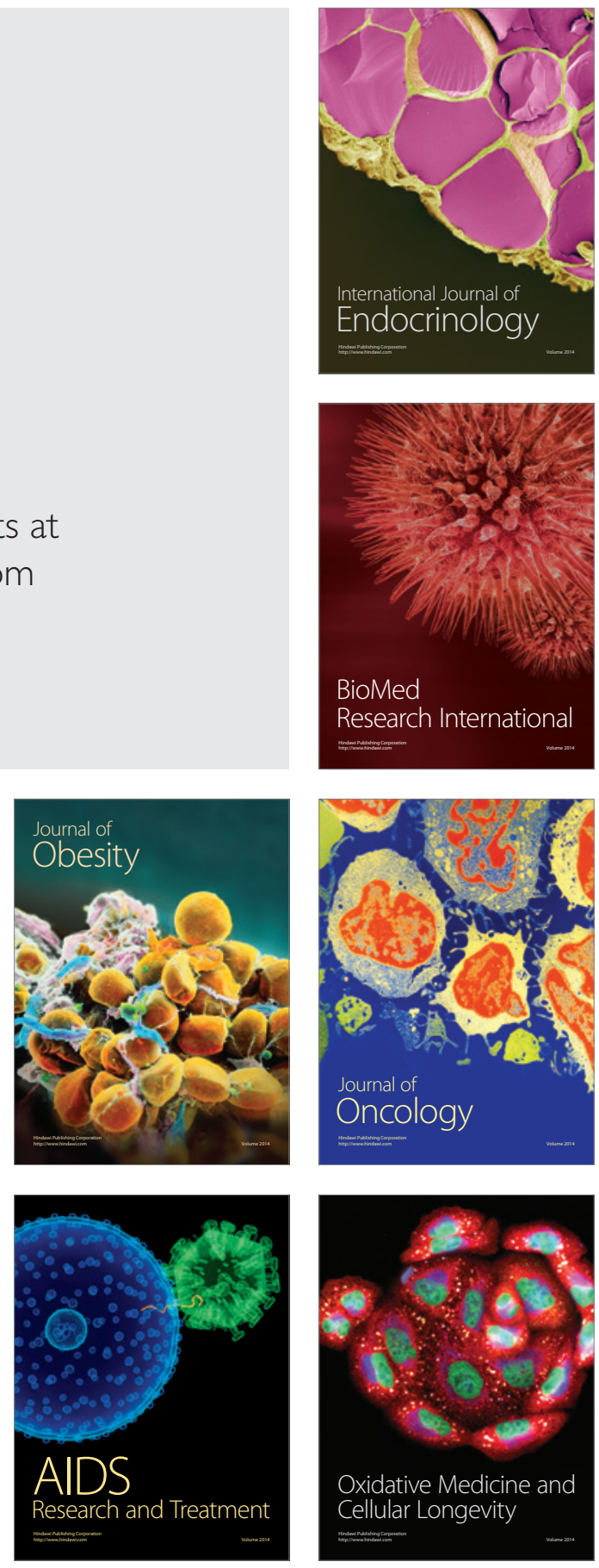